\title{
Complete mitochondrial DNA sequence of the European flat oyster Ostrea edulis confirms Ostreidae classification
}

\author{
Gwenaelle Danic-Tchaleu, Serge Heurtebise, Benjamin Morga and Sylvie Lapègue*
}

\begin{abstract}
Background: Because of its typical architecture, inheritance and small size, mitochondrial (mt) DNA is widely used for phylogenetic studies. Gene order is generally conserved in most taxa although some groups show considerable variation. This is particularly true in the phylum Mollusca, especially in the Bivalvia. During the last few years, there have been significant increases in the number of complete mitochondrial sequences available. For bivalves, 35 complete mitochondrial genomes are now available in GenBank, a number that has more than doubled in the last three years, representing 6 families and 23 genera. In the current study, we determined the complete mtDNA sequence of $O$. edulis, the European flat oyster. We present an analysis of features of its gene content and genome organization in comparison with other Ostrea, Saccostrea and Crassostrea species.
\end{abstract}

Results: The Ostrea edulis mt genome is 16320 bp in length and codes for 37 genes (12 protein-coding genes, 2 rRNAs and 23 tRNAs) on the same strand. As in other Ostreidae, O. edulis mt genome contains a split of the $\mathrm{rrnL}$ gene and a duplication of trnM. The tRNA gene set of O. edulis, Ostrea denselamellosa and Crassostrea virginica are identical in having 23 tRNA genes, in contrast to Asian oysters, which have 25 tRNA genes (except for $C$. ariakensis with 24). O. edulis and $O$. denselamellosa share the same gene order, but differ from other Ostreidae and are closer to Crassostrea than to Saccostrea. Phylogenetic analyses reinforce the taxonomic classification of the 3 families Ostreidae, Mytilidae and Pectinidae. Within the Ostreidae family the results also reveal a closer relationship between Ostrea and Saccostrea than between Ostrea and Crassostrea.

Conclusions: Ostrea edulis mitogenomic analyses show a high level of conservation within the genus Ostrea, whereas they show a high level of variation within the Ostreidae family. These features provide useful information for further evolutionary analysis of oyster mitogenomes.

\section{Background}

Because of its typical architecture, inheritance and small size, animal mitochondrial (mt) DNA is widely used for phylogenetic studies. Combined with these characteristics, its typically maternal inheritance contributes to a fast rate of evolution. Nucleotide changes combined with gene order and rearrangement data can provide valuable information on major evolutionary changes at different taxonomic levels. Typically, animal mtDNA is a compact molecule (14 to $17 \mathrm{~kb}$ ), though some mtDNA can be vastly larger (e.g., Plactopecten magellanicus [1]), and usually encodes 13 proteins, 22 transfer

\footnotetext{
*Correspondence: slapegue@ifremer.fr
IFREMER, Laboratoire de Génétique et Pathologie, F-17390 La Tremblade,

* Correspondence: slapegue@ifremer.fr
IFREMER, Laboratoire de Génétique et Pathologie, F-17390 La Tremblade, France
}

(C) 2011 Lapègue et al; licensee BioMed Central Ltd. This is an open access article distributed under the terms of the Creative Commons Attribution License (http://creativecommons.org/licenses/by/2.0), which permits unrestricted use, distribution, and reproduction in any medium, provided the original work is properly cited.
There are often few intergenic nucleotides except for single large non-coding region generally thought to contain elements that control the initiation of replication and transcription [3]. Size variation in mtDNA is usually due to the different length of the non-coding regions. Gene order is generally conserved in most taxa, although some groups show considerable variation. This is particularly so in the Mollusca phylum, especially in Bivalvia and Scaphopoda [4]. In addition to the fact that phylogenetic relationships among major molluscan groups are not well understood, the species classification of some of the most common mollusks remains difficult.

A case in point is oysters, for which a plastic growth pattern is a major feature, resulting in a wide range of 
overlapping ecophenotypic variants $[5,6]$. Oysters are bivalve molluscs that are widely distributed in the world's oceans. As benthic, sessile filter-feeders, they play an important role in estuarine ecosystems. Moreover, some species are of economic importance, like the Pacific cupped oyster, which is grown in 27 countries and is the most highly produced mollusc species in the world. Oysters have been introduced all over the world for culture and many species are sympatric. Numerous species (30-40 according to the classifications) of oysters of the genus Ostrea have been described. Their geographical range is particularly wide in warm and temperate waters of all oceans, although they have a predominantly tropical distribution [6,7]. In Europe, along the Atlantic and Mediterranean coasts, the European flat oyster, Ostrea edulis, is an important economic marine resource: in 2009 almost 3000 tons were produced in the world, mainly (91\%) in Europe (Spain, France, Ireland ...) [8].

During the last few years, there have been significant increases in the number of complete mitochondrial sequences available for all species. The number has more than doubled for molluscs in the last three years [9], so that 98 complete mollusk mitochondrial genomes are now available in GenBank, mainly from gastropods (43), bivalves (35) and cephalopods (14). Among bivalves, the sequenced genomes represent 6 families and 23 genera. In the Ostreidae, the genus Crassostrea has been thoroughly studied, with 7 representatives (6 Asian oysters and 1 American oyster) [10]. In contrast, there is only one representative of the genus Saccostrea (Saccostrea mordax), and one of the genus Ostrea (Ostrea denselamellosa). Recent studies have provided a more comprehensive picture of the cupped oyster genome, showing an unusually high conservation of mitochondrial gene order in Asian Crassostrea species [11]. Even though molecular tools, such as mitochondrial or microsatellite markers, already exist for the European flat oyster and allow population genetics [12] or quantitative genetics [13] studies, the complete characterization of its mtDNA will allow a better study to be made of phylogenetic relationships among members of the genus, especially between the closely-related species $O$. edulis and O. angasi [14], to improve classification of the Ostreidae family within the Bivalvia.

\section{Results and discussion}

\section{Genome composition}

The complete mitochondrial genome of Ostrea edulis [GenBank: JF274008] is 16320 nt in length and encodes 37 genes, including 12 protein-coding genes (PCGs), 2 rRNAs and 23 tRNAs on the same strand (Figure 1 and Table 1). This size is very close to that of $O$. denselamellosa (16 $277 \mathrm{bp})$, shorter than that of other Ostreidae
(16 532 bp for S. mordax to 22446 bp for C. iredalei), and is within the size range of the Pteriomorphia $\mathrm{mt}$ genomes published to date: from 16211 nt for Argopecten irradians [15] to $32115 \mathrm{nt}$ for Placopecten magellanicus [1].

In the mt genome of O. edulis, a total of 965 bp of non-coding nucleotides is spread over 21 intergenic regions (each over $5 \mathrm{bp}$ ) including a major non-coding region (MNR) of 695 bp. A large non-coding region suggests a putative control region based on its AT content of $74.4 \%$ [16]. In contrast to typical animal mitochondrial genomes, the $O$. edulis genome may lack the protein-coding gene atp 8 , although some recent studies have found a good candidate for atp 8 gene in Mytilidae and possibly in some Ostreidae [17]. Furthermore, $O$. edulis genome also has duplications of three tRNAs: $\operatorname{trn} M, \operatorname{trn} S$ and $\operatorname{trnL}$. The $r r n L$ gene is split into 2 fragments, a phenomenon previously observed in the Ostreidae [11]. The $r r n S$ is not duplicated (also in $O$. denselamellosa, S. mordax and C. virginica), in contrast to Asian Crassostrea.

The molecule has an overall $\mathrm{A}+\mathrm{T}$ composition value of $64.9 \%$ and the size of the coding region is $15379 \mathrm{nt}$ in length, accounting for $94.2 \%$ of the whole genome. The AT content is slightly higher than those of Pectinidae (55.3 to $59.6 \%$ [18]) or Mytilidae (61.5 to $61.8 \%$ ). The AT composition of $O$. edulis is, therefore, within the AT content range of the Ostreidae: the lowest known AT content is $60.7 \%$ in $O$. denselamellosa, while the highest is $65.3 \%$ in C. hongkongensis [19]. In S. mordax, the AT content is $64.4 \%$ which is very similar to O. edulis.

As observed in O. denselamellosa (16 277 bp), S. mor$\operatorname{dax}(16,532 \mathrm{bp})$ and C. virginica (17 $244 \mathrm{bp})$, the lack of duplicated $r r n S$ in $O$. edulis, added to the lack of 2 tRNAs (not duplicated trn-K and trn-Q) compared to Asian Crassostrea may account for the difference in length compared with other Crassostrea (C. gigas 18225 bp, C. hongkongensis $18622 \mathrm{bp}$ ).

The genome composition of $O$. edulis is, thus, identical to O. denselamellosa (except for AT composition) and close to $S$. mordax in terms of complete genome size, AT content and the non-duplicated $r r n S$. More mitochondrial genome sequences from Ostrea and Saccostrea will be needed to assess relationships between the Ostrea, Crassostrea and Saccostrea genera.

\section{Gene arrangement}

Animal mt gene order is relatively stable within major groups and generally variable among groups [2]. Bivalve species show variability in terms of $\mathrm{mt}$ genome size, gene arrangement and tRNA number [20]. As observed in four Pectinidae (A. irradians, M. yessoensis, C. farreri and $P$. magellanicus), gene arrangement can be very different despite species being members of the same family 


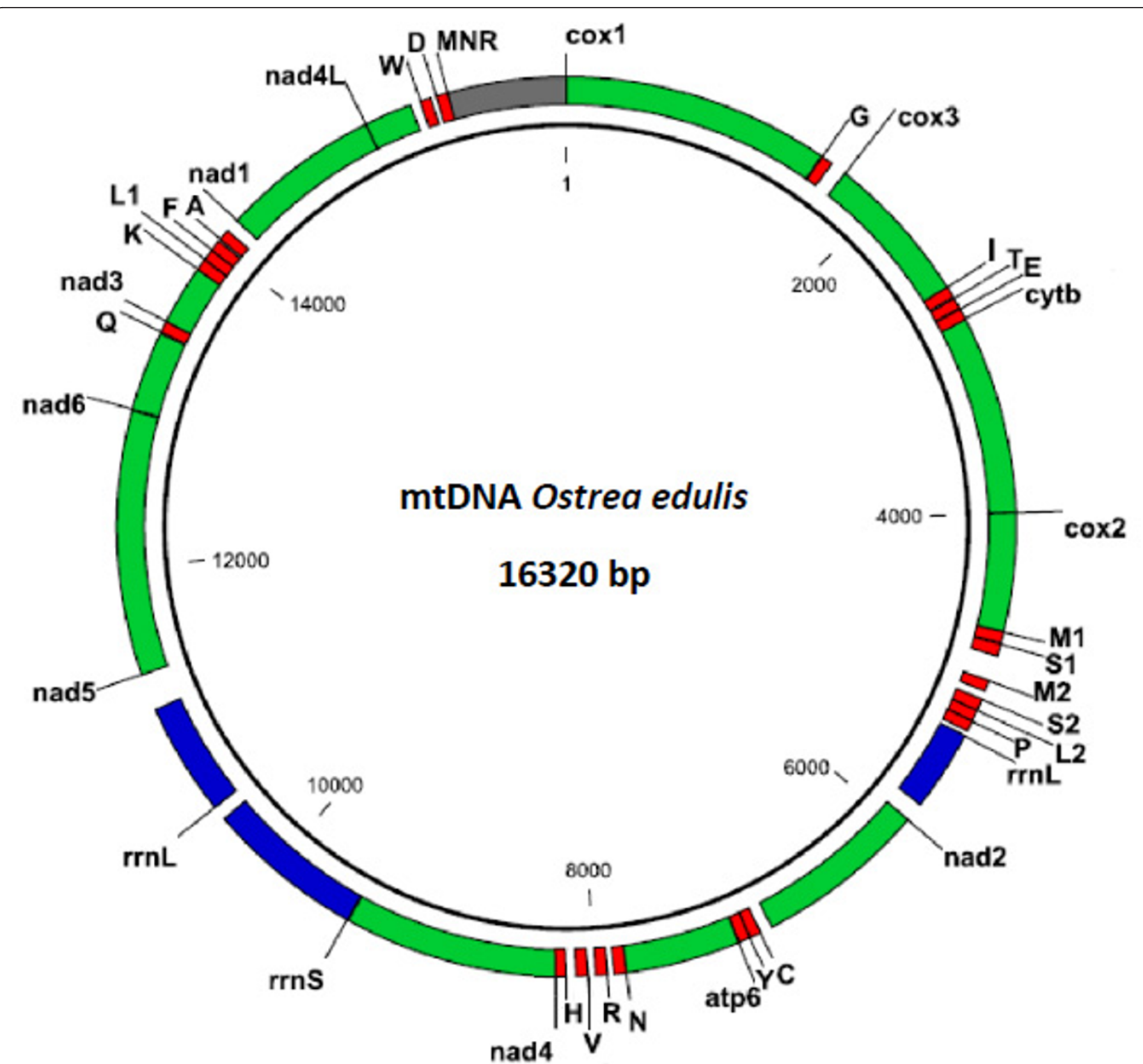

Figure 1 Mitochondrial genome map of Ostrea edulis. Genes for proteins (green) and rRNAs (blue) are abbreviated with standard abbreviations. The one letter amino acid code is used for tRNA (red) designation. The major non-coding region (MNR) is shown in grey.

[15]. In contrast, in Mytilus congeners M. edulis, $M$. trossulus and M. galloprovincialis, PCGs are arranged in an identical order, but tRNA, rRNA and control regions are also almost the same [21]. The mt gene order of $O$. edulis is identical to that of $O$. denselamellosa (Figure 2 ). The arrangement of PCGs in O. edulis is cox1, cox3, cytb, cox2, nad2, atp6, nad4, nad5, nad6, nad3, nad1, nad $4 L$ and is nearly identical to that of Crassostrea, except for the inversion of two PCGs nad2 and atp6. Among the six Asian Crassostrea and their Atlantic sister species C. virginica, only protein-coding gene order is identical [10]. Besides, gene order of Crassostrea differs significantly from S. mordax. Ostreidae share three
PCG blocks cox1-cox3-cytb-cox2, nad5-nad6 and nad3nad1-nad4L. Moreover, the nad2-atp6-nad4 block of $O$. edulis is inverted in S. mordax (Figure 2), but the remaining genes are extensively rearranged. The major non-coding region (MNR) is located after $\operatorname{trn} D$ (Figure 1 ), while this region is found between $\operatorname{trn} G$ and $\operatorname{trn} V$ near atp6 and nad2 in Crassostrea. If tRNAs and rRNAs are considered, there are six blocks conserved within the Ostreidae: cox3-trnI, cox2-trnM, trnM-trnS, trnY-atp6, trnH-nad4 and trnF-trnA-nad1-nad4L. Between O. edulis and Asian Crassostrea, seven blocks are shared: cox3trnI-trnT-trnE-cytb, cox2-trnM-trnS, trnM-trnS, trnYatp6, trnH-nad4, nad5-nad6-trnQ-nad3 and trnL-trnF- 
Table 1 Features of Ostrea edulis mitochondrial genome

\begin{tabular}{|c|c|c|c|c|c|}
\hline Feature & Sequence location & Size & Start codon & Stop codon & Intergenic region* \\
\hline $\operatorname{cox} 1$ & $1-1566$ & 1566 & ATG & TAA & 6 \\
\hline $\operatorname{trnG}$ & 1573-1639 & 67 & & & 95 \\
\hline $\operatorname{cox} 3$ & $1735-2622$ & 888 & ATA & TAG & -1 \\
\hline $\operatorname{trnl}$ & $2622-2687$ & 66 & & & 10 \\
\hline $\operatorname{trnT}$ & $2698-2761$ & 64 & & & 7 \\
\hline $\operatorname{trn} E$ & $2769-2836$ & 68 & & & -6 \\
\hline cytb & 2831-3997 & 1167 & CTA & TAA & 1 \\
\hline $\operatorname{cox} 2$ & $3999-4691$ & 693 & ATG & TAA & 3 \\
\hline $\operatorname{trnM1}$ & $4695-4759$ & 65 & & & 7 \\
\hline $\operatorname{trnS1}$ & $4767-4836$ & 70 & & & 151 \\
\hline $\operatorname{trnM2}$ & $4988-5051$ & 64 & & & 51 \\
\hline $\operatorname{trnS2}$ & 5103-5172 & 70 & & & 1 \\
\hline $\operatorname{trnL} 1$ & 5173-5239 & 67 & & & 1 \\
\hline $\operatorname{trn} P$ & $5241-5304$ & 64 & & & 17 \\
\hline rrnL 5'end & $5322-5896$ & 575 & & & 25 \\
\hline nad2 & $5922-6929$ & 1008 & ATT & TAA & 73 \\
\hline $\operatorname{trn} C$ & 7003-7066 & 64 & & & 3 \\
\hline $\operatorname{trn} Y$ & 7070-7134 & 65 & & & 6 \\
\hline atp6 & 7141-7809 & 669 & ATA & TAG & 3 \\
\hline $\operatorname{trnN}$ & 7813-7883 & 71 & & & 14 \\
\hline $\operatorname{trn} R$ & 7898-7964 & 67 & & & 4 \\
\hline trnV & 7969-8035 & 67 & & & 27 \\
\hline $\operatorname{trnH}$ & 8063-8126 & 64 & & & -15 \\
\hline nad4 & $8112-9476$ & 1365 & ATA & TAG & 0 \\
\hline rrns & $9477-10411$ & 935 & & & 81 \\
\hline rrnL 3'end & $10493-11200$ & 708 & & & 172 \\
\hline nad5 & 11373-12920 & 1548 & ATG & TAA & 7 \\
\hline nad6 & 12928-13395 & 468 & ATA & TAA & 9 \\
\hline $\operatorname{trnQ}$ & $13405-13470$ & 66 & & & 1 \\
\hline nad3 & $13472-13825$ & 354 & ATG & TAG & -1 \\
\hline trnK & 13825-13891 & 67 & & & 3 \\
\hline $\operatorname{trnL2}$ & $13895-13960$ & 66 & & & 1 \\
\hline $\operatorname{trnF}$ & $13962-14028$ & 67 & & & 13 \\
\hline $\operatorname{trn} A$ & $14042-14106$ & 65 & & & 79 \\
\hline nad1 & 14186-15118 & 933 & ATG & TAA & 1 \\
\hline nad4L & 15120-15401 & 282 & ATG & TAA & 60 \\
\hline trnW & $15462-15524$ & 63 & & & 33 \\
\hline $\operatorname{trnD}$ & 15558-15625 & 68 & & & 0 \\
\hline MNR & $15626-16320$ & 695 & & & 0 \\
\hline
\end{tabular}

*Negative numbers indicate overlapping nucleotides between adjacent genes

trnA-nad1-nad4L-trnW; while between O. edulis and S. mordax, seven blocks are also shared but these are different: trnG-cox3-trnI, trnE-cytb-cox2-trnM, trnM-trnStrnL-trnP-rrnL(5'end), trnF-trnA-nad1-nad4L, $\operatorname{rrnL}$ (3'end)-nad5-nad6, trnH-nad4 and trnY-atp6. It should be noted that $r r n L$ is in one piece in Saccostrea but not within Crassostrea.

In terms of gene arrangement, it is thus clear that $O$. edulis is more similar to Crassostrea than to $S$. mordax when comparing PCGs. As shown in Figure 2, the complete genome arrangement of $O$. edulis is similar to that of Asian Crassostrea while it appears completely reorganized from $\operatorname{trn} Y$ to the end of $\mathrm{mt}$ genome when compared with that of S. mordax.

\section{Protein-coding genes}

All PCGs are encoded on and transcribed from the same strand. Twelve open reading frames (ORFs) were detected for the thirteen typical PCGs (cox1-cox3, cytb, nad1-nad6, nad4L, atp6 and atp8). Although we 


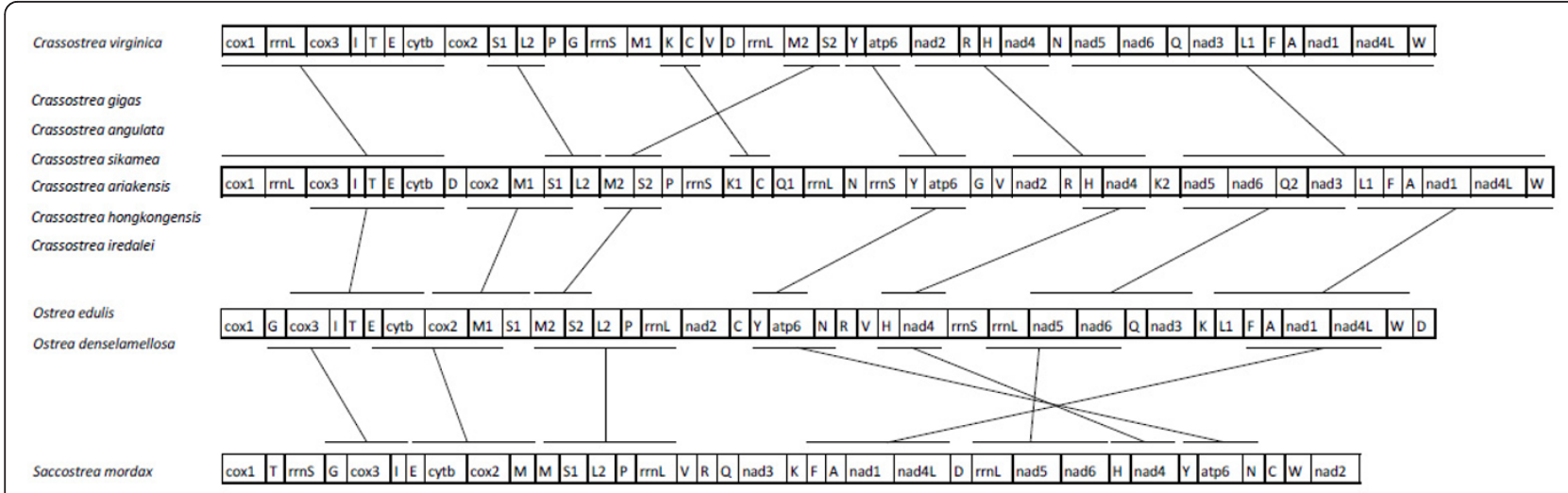

Figure 2 The gene arrangement map of Ostreidae mitochondrial genomes. The bars show identical gene blocks. All genes are transcribed from left-to-right.

carefully looked for candidate regions for atp 8 gene, we could not identify any, as in all Pteriomorphia complete genomes already published. However, a recent publication [17] suggests that a putative ORF represents a good candidate to start an atp 8 gene in most bivalve mt genomes. Within the invertebrate mt code there are three standard initiation codons (M-AUG, M-AUA, and IAUU), but mt genomes often use a variety of non conventional start codons [22]. In this study, most of PCGs use conventional initiation codons: ATA is used for cox3, nad4, nad6 and atp6; ATG is used for cox1, cox2, nad1, nad3, nad4L and nad5; ATT is used for nad2, but $c y t b$ uses the alternative start codon CTA (as in C. gigas and C. angulata [10]). Eight protein-coding genes were terminated by a stop codon (TAA and TAG).

\section{Transfer and ribosomal RNA genes}

In total, 23 tRNA coding genes were identified in the size range of 63 to 71 nucleotides, based on typical secondary structure (Additional file 1). An additional $\operatorname{trn} M$ was detected as found in C. gigas, C. hongkongensis [9], C. virginica [16] and Mytilus [23]. Two serine and two leucine tRNA genes were also differentiated in O. edulis by their anticodons (UCA Ser1, AGA Ser2, and CUA Leu1, UUA Leu2) as found in O. denselamellosa [24], Crassostrea and some other species (M. edulis, M. galloprovincialis and Argopecten irradians). The anticodon usage of O. edulis was congruent with the corresponding tRNA genes of other molluscan mtDNAs.

Identification of both the small and the large ribosomal RNA genes in O. edulis was accomplished by BLAST comparison with other published ribosomal RNA genes, especially $O$. denselamellosa [GenBank: HM015199], S. mordax [GenBank:FJ841968] and C. gigas [GenBank:EU672831]. Although putative gene boundaries for the two rRNA genes have been found, these cannot be precisely determined until transcript mapping is carried out. Besides rrnS of O. edulis is 935 bp in length and flanked by nad4 and $r r n L$ 3'end.

The $\operatorname{rrn} L$ gene is split into two segments: one segment, of the 5 ' end (matches with rrnL 5'end from $O$. denselamellosa and Saccostrea), is 575 bp long and positioned between $\operatorname{trn} P$ and $n a d 2$; and the other segment, of the 3' end, is $708 \mathrm{bp}$ and located between $r r n S$ and nad5. The length of the $r r n S$ is similar to that of most bivalves, but smaller than that of O. denselamellosa (1017 bp) and that of Crassostrea (946 to $1207 \mathrm{bp}$ ) [10]. The size of $r r n L$ (1283 bp in all) is similar to that of O. denselamellosa (1299 bp), but smaller than that of other bivalves. This bias may be due to the method (BLAST) used to compare the rRNA sequences because this method only checks the identity between a few sequences and because it's easier to compare sequences from same species as they show higher identity.

\section{Non-coding regions}

As in most bivalves, O. edulis mtDNA contains a large number of unassigned nucleotides. There are as many as 21 non-coding regions (> $5 \mathrm{bp}$ ) up to 965 nucleotides found throughout the $O$. edulis mitochondrial genome. Eight of these non-coding regions are more than $50 \mathrm{bp}$ in length. Among these regions, the major non-coding region (MNR) has been identified and located, that remains the most promising region in which to find regulatory and/or gender-specific sequences [25]. The $O$. edulis mtDNA MNR is positioned between $\operatorname{trn} D$ and cox 1 and is $695 \mathrm{bp}$ in length, similar to that of $O$. denselamellosa (689 bp), making it the longest MNR within the Ostreidae apart from C. virginica (832 bp) and $C$. ariakensis (716 bp). It has an $\mathrm{A}+\mathrm{T}$ content of $74.4 \%$ which is higher than the remainder of the $\mathrm{mt}$ genome (64.4\%), as it includes several (A)n and (T)n homopolymer tracts, features which are typically used for 
identification of the mitochondrial control region and thought to contain the replication origin [2].

\section{Phylogenetic analysis}

In recent years there have been many phylogenetic studies on the taxonomy and evolution of the Ostreidae based on molecular data, especially mitochondrial DNA [26-30]. However, most of these previous studies have been based on partial sequences and incomplete molecular information. Recently, Ren et al. [11] have compared 7 complete mt genomes from Asian oysters.

In the present study's aa-based tree built with twelve concatened PCGs from 19 mitochondrial genomes in Pteromorphia (Figure 3), we can observe that, at the Ostreidae level, O. edulis is first clustered with O. denselamellosa as congeneric species. Then this group of species falls into a highly supported clade with $S$. mordax. Ostrea and Saccostrea are then clustered with the Crassostrea species group. In this latest clade, the single American oyster $C$. virginica falls at the base of a nested clade that contains the Asian oysters. Very similar results were obtained with a nucleotide phylogenetic tree with low differences of bootstrap values. In Figure 4 , more Ostreidae species are included as more numerous cox1 sequences are available in Genbank. The same phylogenetic relationship between Ostrea, Saccostrea, and Crassostrea is observed, especially the first grouping of Ostrea and Saccostrea, but not between Ostrea and Crassostrea, with however far less robust nodes. This same result was observed when considering the evolution of the tRNA anticodons in marine bivalve mitochondrial genomes, where the relationship presented are also based on concatenated nucleotide sequences of 12 protein-coding genes by Bayesian inference analysis [24]. However a recent study [31], based on cox1 and $16 \mathrm{~S}$ sequences, showed a closer relationship between Ostrea and Crassostrea, than with Ostrea and Saccostrea. However, for the cox 1 analysis, only one Ostrea sequence was included, and for the $16 \mathrm{~S}$ analysis, much more Ostrea sequences were included but the bootstrap value was between 50 and $80 \%$. Those comparisons seem to indicate that phylogenetic analyses are more powerful when including several sequences as the 12 concatened PCGs.

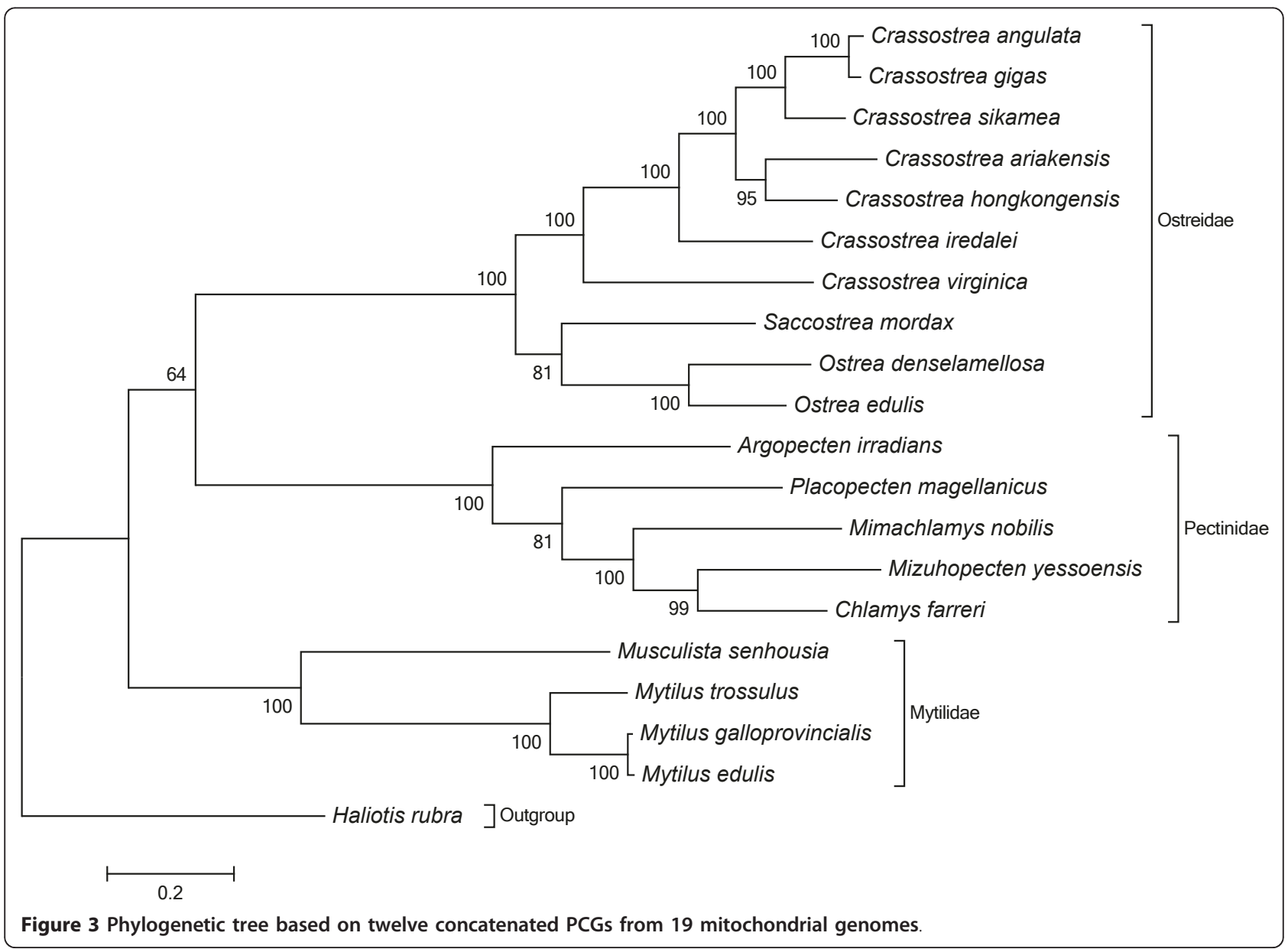




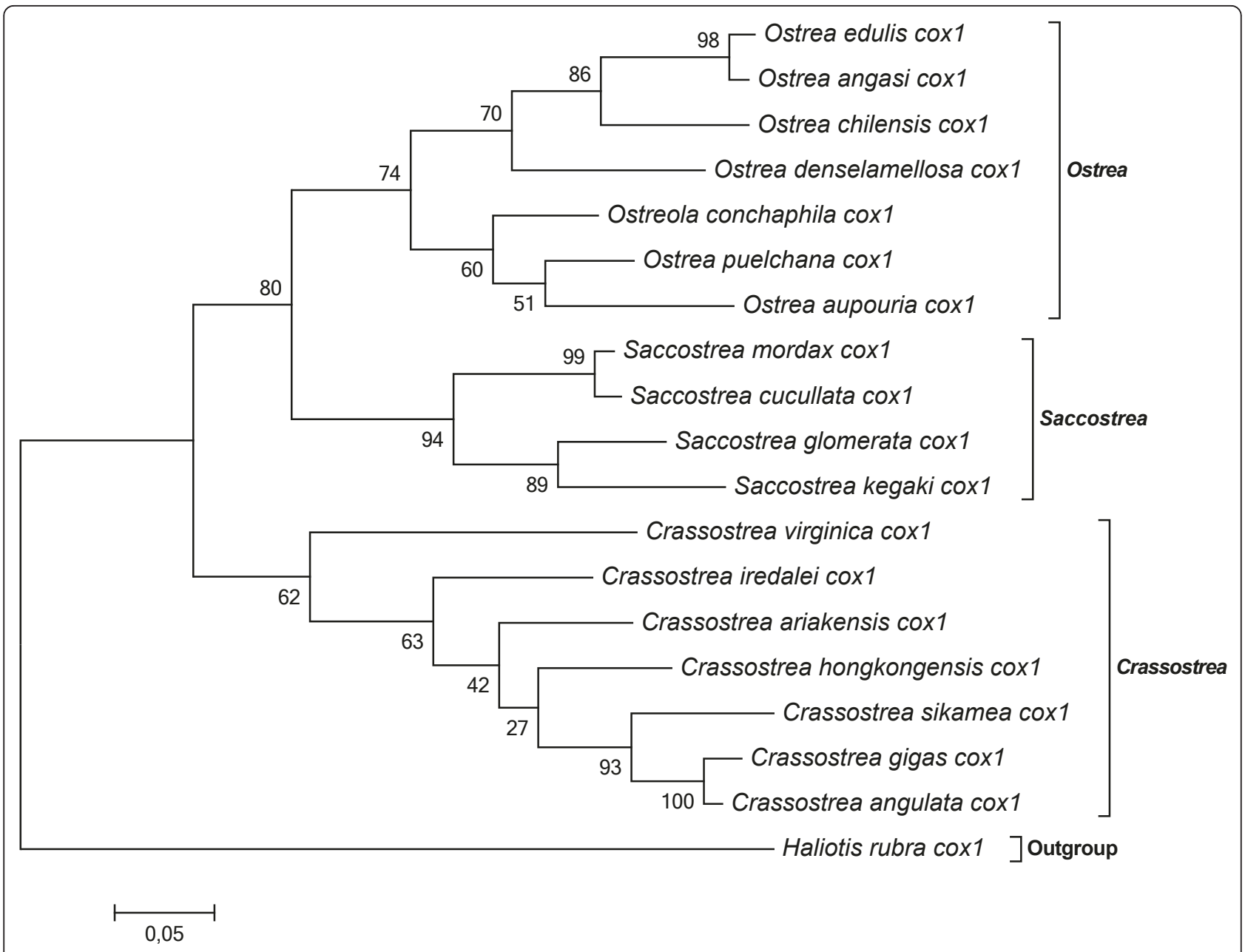

Figure 4 Phylogenetic tree based on cox1 from all published Ostrea, Ostreola, Saccostrea and Crassostrea.

Finally, the phylogenetic tree presented in Figure 3, which includes mt genomes from all published Pteriomorphia, reinforces the taxonomic classification of the 3 families Ostreidae, Mytilidae and Pectinidae [32,11].

\section{Conclusion}

In conclusion, the complete mitochondrial genome of $O$. edulis is $16320 \mathrm{bp}$ in length. A common phenomenon is that mitogenomes of most bivalves contain two trnM genes and most metazoan mitochondria have a set of 22 tRNA, including two trnL and two trnS. However the tRNA gene sets of O. edulis, O. denselamellosa and $C$. virginica are identical in having 23 tRNA genes. Another important characteristic is that the $r r n S$ gene is not duplicated in O. edulis, a feature shared with O. denselamellosa, S. mordax and C. virginica and which contrasts with Asian Crassostrea.

The phylogenetic analyses confirm the relationships between each family (Ostreidae, Mytilidae and Pectinidae), but also within each genus (Ostrea, Saccostrea and
Crassostrea). Within the Ostreidae, phylogenetic analyses show that Ostrea are closer to Saccostrea than Crassostrea, although gene arrangement may show a closer relationship between Ostrea and Crassostrea, indicating that several types of information are needed to infer relationships between genome species as evolution is acting at different levels of the genomes. As many questions remain unanswered on the phylogeny of Ostreidae, especially between Ostrea and Saccostrea, it would be desirable to increase the resolution by adding samples of more taxa in order to extend molecular information among the major lineages of the Ostreidae and within the Pteriomorphia as a whole.

\section{Methods}

PCR amplification and DNA sequencing

Adductor muscle from three O. edulis collected in Quiberon Bay (Bretagne, France) was used in this study. Total genomic DNA was extracted using a Wizard ${ }^{\circledR}$ DNA Clean-up System (Promega). The 
mitochondrial genome was amplified in 4 overlapping fragments using species-specific primers (Additional file 2). PCR was performed in $25 \mu \mathrm{l}$ reaction volumes in a thermocycler (Applied Biosystems). Each reaction contained $13.3 \mu \mathrm{l} \mathrm{dH} 2 \mathrm{O}, 5.0 \mu \mathrm{l}$ buffer $5 \times$ (Promega), $2.0 \mu \mathrm{l} \mathrm{MgCl} 2(25 \mathrm{mM}), 2.5 \mu \mathrm{ldNTP}(2 \mathrm{mM}), 0.5 \mu \mathrm{l}$ of each primer $(20 \mu \mathrm{M})$, and $0.2 \mu \mathrm{l} \mathrm{GoTaq}{ }^{\circledR} \mathrm{DNA}$ polymerase $(5 \mathrm{U} / \mu \mathrm{l}$, Promega). PCR cycling conditions were $94{ }^{\circ} \mathrm{C}$ for $2 \mathrm{~min}$; then 30 cycles of $94{ }^{\circ} \mathrm{C}$ for $30 \mathrm{sec}, 57$ ${ }^{\circ} \mathrm{C}$ for $30 \mathrm{sec}$ and $72{ }^{\circ} \mathrm{C}$ for $2 \mathrm{~min}$; and finally a step of $72{ }^{\circ} \mathrm{C}$ for $10 \mathrm{~min}$. PCR products were verified by electrophoresis (1\% agarose gel) and purified using Montage ${ }^{\circledR}$ PCR Centrifugal Filter Devices (Millipore). Purified products were then used directly as templates in cycle sequencing reactions with dyelabeled terminators (Big Dye 3.1, Applied Biosystems). Specific primers were designed and used for primer walking sequencing, which was performed for both strands of each sample on an ABI 3130XL/Genetic Analyser (ABI).

\section{Sequence analysis and gene annotation}

During the processing of large fragments and those from primer walking sequencing, regular and manual examinations were used to ensure there was reliable overlapping and correct genome assembly.
Protein-coding and ribosomal RNA genes were firstly identified using BLAST [33] searches at GenBank, and then by alignment with previously published $\mathrm{mt}$ genomes from species of Crassostrea, Saccostrea and other closely-related molluscs. Amino-acid sequences of protein-coding genes were inferred with ORF Finder [34] using invertebrate mitochondrial genetic code. Transfer RNAs were identified using DOGMA [35]http://dogma. ccbb.utexas.edu/, and tRNAscan-SE [36]http://selab.janelia.org/tRNAscan-SE/ using mito/chloroplast genetic code and default search mode, or setting the cove cutoff score to 1 when necessary. Assembly of the genome and gene map of the mitochondrial genome of Ostrea edulis was performed using CLC Main Workbench (CLC bio).

\section{Phylogenetic analysis}

To date, 20 Pteriomorphia mt genomes are available in GenBank [37] and we used 19 of these (excluding Argopecten irradians irradians that is very close to Argopecten irradians: $99 \%$ similarity) in our phylogenetic analysis, together with $O$. edulis $\mathrm{mt}$ genome obtained in this study (Table 2). The blacklip abalone Haliotis rubra (Gastropoda) was used as the outgroup. The nucleotide and amino-acid sequences from all 12 PCGs (proteincoding genes) were concatenated for each genome and

Table 2 List of complete mitogenomes used in this study

\begin{tabular}{|c|c|c|c|}
\hline Tax on & Classification & GenBank Accession Number & Size \\
\hline \multicolumn{4}{|l|}{ Mollusca } \\
\hline \multicolumn{4}{|l|}{ Bivalvia } \\
\hline \multicolumn{4}{|l|}{ Pteriomorphia } \\
\hline Mytilus edulis & Mytiloida; Mytiloidea; Mytilidae & AY484747 & $16,740 \mathrm{nt}$ \\
\hline Mytilus galloprovincialis & Mytiloida; Mytiloidea; Mytilidae & AY497292 & $16,744 \mathrm{nt}$ \\
\hline Mytilus trossulus & Mytiloida; Mytiloidea; Mytilidae & AY823625 & $18,652 \mathrm{nt}$ \\
\hline Musculista senhousia & Mytiloida; Mytiloidea; Mytilidae & GU001954 & $20,612 n t$ \\
\hline Crassostrea angulata & Ostreoida; Ostreoidea; Ostreidae & EU672832 & $18,225 \mathrm{nt}$ \\
\hline Crassostrea ariakensis & Ostreoida; Ostreoidea; Ostreidae & EU672835 & $18,414 \mathrm{nt}$ \\
\hline Crassostrea gigas & Ostreoida; Ostreoidea; Ostreidae & EU672831 & $18,225 \mathrm{nt}$ \\
\hline Crassostrea hongkongensis & Ostreoida; Ostreoidea; Ostreidae & EU672834 & $18,622 \mathrm{nt}$ \\
\hline Crassostrea iredalei & Ostreoida; Ostreoidea; Ostreidae & FJ841967 & $22,446 \mathrm{nt}$ \\
\hline Crassostrea sikamea & Ostreoida; Ostreoidea; Ostreidae & EU672833 & $18,243 \mathrm{nt}$ \\
\hline Crassostrea virginica & Ostreoida; Ostreoidea; Ostreidae & Y905542 & $17,244 \mathrm{nt}$ \\
\hline Saccostrea mordax & Ostreoida; Ostreoidea; Ostreidae & FJ841968 & $16,532 \mathrm{nt}$ \\
\hline Ostrea denselamellosa & Ostreoida; Ostreoidea; Ostreidae & HM015199 & $16,277 \mathrm{nt}$ \\
\hline Ostrea edulis & Ostreoida; Ostreoidea; Ostreidae & $J F 274008$ & $16,320 \mathrm{nt}$ \\
\hline Argopecten irradians & Pectinoida; Pectinoidae; Pectinidae & EU023915 & $16,221 \mathrm{nt}$ \\
\hline Chlamys farreri & Pectinoida; Pectinoidae; Pectinidae & EU715252 & $21,695 \mathrm{nt}$ \\
\hline Mizuhopecten yessoensis & Pectinoida; Pectinoidae; Pectinidae & AB271769 & $20,414 \mathrm{nt}$ \\
\hline Placopecten magellanicus & Pectinoida; Pectinoidae; Pectinidae & DQ088274 & $32,115 \mathrm{nt}$ \\
\hline Mimachlamys nobilis & Pectinoida; Pectinoidea; Pectinidae & FJ415225 & $17,963 \mathrm{nt}$ \\
\hline \multicolumn{4}{|l|}{ Gastropoda } \\
\hline \multicolumn{4}{|l|}{ Vetigastropoda } \\
\hline Haliotis rubra & Haliotoidea; Haliotidae & NC_005940 & $16,907 \mathrm{nt}$ \\
\hline
\end{tabular}


aligned using MUSCLE [38]. The size of the concatenated alignment nucleotides varied from $10411 \mathrm{bp}$ for M. yessoensis to $11240 \mathrm{bp}$ for $P$. magellanicus). To the alignments, we applied a Maximum Likelihood (ML) phylogenetic reconstruction approach using 100 bootstraps with MEGA5 [39]. A second phylogenetic analysis was performed using 5 additional coxl genes from Ostrea (Ostrea angasi [GenBank:AF112287.1], Ostrea aupouria [GenBank:AF112288.1], Ostrea chilensis [GenBank:AF112289.1], Ostrea puelchana [GenBank: DQ226521.1], and Ostreola conchaphila [GenBank: DQ464125.1]) and 3 from Saccostrea (Saccostrea cucullata [GenBank:AY038076.1], Saccostrea glomerata [GenBank:EU007483.1] and Saccostrea kegaki [GenBank: AB076910.1]).

\section{Additional material}

Additional file 1: The potential secondary structures of 22 tRNAs of Ostrea edulis. The duplication of methionine is named M1 and M2 respectively. Codons recognized are shown for the pairs of leucine (L1 and L2) and serine (S1 and S2).

Additional file 2: Primers used for amplification of 4 large fragments in mitochondrial genome of Ostrea edulis.

\section{Acknowledgements}

The authors thank Aimé Langlade who provided biological material, Denis Saulnier who gave valuable advice, Nicole Faury for her technical assistance and Helen McCombie for English editing. We also thank two anonymous reviewers for their useful comments on the manuscript.

\section{Authors' contributions}

GDT, SH and BM obtained the sequences. GDT and SL performed analyses and wrote the first draft of the publication. All the co-authors finalised the manuscript.

\section{Competing interests}

The authors declare that they have no competing interests.

Received: 9 June 2011 Accepted: 12 October 2011

Published: 12 October 2011

\section{References}

1. Smith DR, Snyder M: Complete Mitochondrial DNA sequence of the scallop Placopecten magellanicus: evidence of transposition leading to an uncharacteristically large mitochondrial genome. J Mol Evol 2007, 65:380-391.

2. Boore JL: Animal mitochondrial genomes. Nucleic Acids Res 1999, 27:1767-1780

3. Shadel GS, Clayton DA: Mitochondrial DNA maintenance in vertebrates. Annu Rev Biochem 1997, 66:409-435.

4. Serb JM, Lydeard C: Complete mtDNA sequence of the North American freshwater mussel, Lampsilis ornate (Unionidae): An examination of the evolution and phylogenetic utility of mitochondrial genome organization in Bivalvia (Mollusca). Mol Biol Evol 2003, 20:1854-1866.

5. Ranson G: Les huitres: biologie, culture Paul Lechevalier, Paris; 1951.

6. Barnabe G: Aquaculture: biology and ecology of cultured species Ellis Horwood Series in Aquaculture and Fisheries Support, Wiley \& Sons, Chichester, UK; 1994

7. Jaziri H: Variations génétiques et structuration biogéographique chez un bivalve marin: I'huître plate Ostrea edulis (L). PhD thesis Université Montpellier II-Sciences et Techniques du Languedoc; 1990.
8. FAO: Global Aquaculture production 1950-2009. 2009 [http://www.fao. org/fishery/statistics/global-aquaculture-production/en].

9. Yu Z, Wei Z, Kong X, Shi W: Complete mitochondrial DNA sequence of oyster Crassostrea hongkongensis-a case of "Tandem duplication-random loss" for genome rearrangement in Crassostrea? BMC Genomics 2008, 9:477

10. Wu X, Xu X, Yu Z, Wei Z, Xia J: Comparison of seven Crassostrea mitogenomes and phylogenetic analyses. Molecular Phylogenetics and Evolution 2010, 57(1):448-454.

11. Ren J, Liu X, Jiang F, Guo X, Liu B: Unusual conservation of mitochondrial gene order in Crassostrea oysters: evidence for recent speciation in Asia. BMC Evolutionary Biology 2010, 10:394

12. Diaz-Almela $E$, Boudry $P$, Launey $S$, Bonhomme $F$, Lapègue $S$ : Comparison of mitochondrial DNA and microsatellites variation along the range of the European flat oyster Ostrea edulis. J Hered 2004, 95:510-516.

13. Lallias $D$, Stockdale R, Boudry $P$, Beaumont AR, Lapègue $S$ : Characterization of 27 microsatellite loci in the European flat oyster Ostrea edulis. Molecular Ecology Resources 2009, 9(3):960-963.

14. Morton B, Lam K, Black-Smith S: First report of the European flat oyster Ostrea edulis, identified genetically, from oyster harbour, Albany, SouthWestern Australia. Molluscan Research 2003, 23:199-208.

15. Ren J, Shen X, Jiang F, Liu B: The mitochondrial genomes of two scallops, Argopecten irradians and Chlamys farreri (Mollusca: Bivalvia): the most highly rearranged gene order in the family Pectinidae. J Mol Evol 2010, 70(1):57-68.

16. Milbury CA, Gaffney PM: Complete mitochondrial DNA sequence of the eastern oyster Crassostrea virginica. Mar Biotechnol 2005, 7:697-712.

17. Breton S, Stewart DT, Hoeh WR: Characterization of a mitochondrial ORF from the gender-associated mtDNAs of Mytilus spp. (Bivalvia: Mytilidae): Identification of the "missing" ATPase 8 gene. Marine Genomics 2010, 3:11-18.

18. $W u X, X u X, Y u Z$, Kong $X$ : Comparative mitogenomic analyses of three scallops (Bivalvia: Pectinidae) reveal high level variation of genomic organization and a diversity of transfer RNA gene sets. BMC Res Notes 2009, 2:69.

19. Ren J, Liu X, Zhang G, Liu B, Guo X: "Tandem duplication-random loss" is not a real feature of oyster mitochondrial genomes. BMC Genomics 2009, 10:84

20. Gissi C, lannelli F, Pesole G: Evolution of the mitochondrial genome of Metazoa as exemplified by comparison of congeneric species. Heredity 2008, 101:301

21. Mizi A, Zouros E, Moschonas N, Rodakis GC: The complete maternal and paternal mitochondrial genomes of the Mediterranean mussel Mytilus galloprovincialis: implications for the doubly uniparental inheritances mode of mtDNA. Mol Biol Evol 2005, 22:952-967.

22. Wolstenholme DR: Animal mitochondrial DNA: structure and evolution. Int Rev Cytol 1992, 141:173-216.

23. Hoffman RJ, Boore JL, Brown WM: A novel mitochondrial genome organization for the blue mussel, Mytilus edulis. Genetics 1992 131:397-412.

24. Yu H, Li Q: Mutation and Selection on the Wobble Nucleotide in tRNA Anticodons in Marine Bivalve Mitochondrial Genomes. PLoS One 2011, 186(1):e16147

25. Breton S, Doucet Beaupré H, Stewart DT, Piontkivsha H, Karmakar M, Bogan AE, Blier PU, Hoeh WR: Comparative mitochondrial genomics of freshwater mussels (Bivalvia: Unionoida) with Doubly Uniparental Inheritance of mtDNA: gender-specific Open Reading Frames (ORFs) and putative origins of replication. Genetics 2009, 183:1575-1589.

26. Boore JL, Brown WM: Big trees from little genomes: mitochondrial gene order as a phylogenetic tool. Curr Opin Genet Dev 1998, 8:668-674.

27. Boudry P, Heurtebise S, Collet B, Cornette F, Gérard A: Differentiation between populations of the Portuguese oyster, Crassostrea angulata (Lamarck), and the Pacific oyster, Crassostrea gigas (Thunberg), revealed by mtDNA RFLP analysis. Journal of Experimental Marine Biology and Ecology 1998, 226:279-291.

28. Klinbunga S, Khamnamtong B, Puanglarp N, Jarayabhand P, Yoosukh W, Menasveta P: Molecular taxonomy of cupped Oysters (Crassostrea, Saccostrea and Striostrea) in Thailand based on COI, 16S, and 18S rDNA polymorphism. Marine Biotechnology 2005, 7:306-317.

29. Lam K, Morton B: Morphological and mitochondrial-DNA analysis of the Indo-West Pacific rock oysters (Ostreidae Saccostrea species). J Mollus Stud 2006, 72(3):235-245 
30. Reece KS, Cordes JF, Stubbs JB, Francis E, Hudson K: Molecular phylogenies help resolve taxonomic confusion with Asian Crassostrea oyster species. Marine Biology 2008, 153:709-721.

31. Liu J, Li Q, Kong L, Yu H, Zheng X: Identifying the true oysters (Bivalvia: Ostreidae) with mitochondrial phylogeny and distance-based DNAbarcoding. Molecular Ecology Resources 2011, 11:820-830.

32. Giribet $G$, Wheeler $W$ : On bivalve phylogeny: a high-level analysis of the Bivalvia (Mollusca) based on combined morphology and DNA sequence data. Invertebrate Biology 2002, 121(4):271-324.

33. The Basic Local Alignment Search Tool (BLAST). [http://www.ncbi.nlm.nih. gov/BLAST/].

34. NCBI Open Reading Frame Finder. [http://www.ncbi.nlm.nih.gov/gorf/gorf. html].

35. Wyman SK, Jansen RK, Boore JL: Automatic annotation of organellar genomes with DOGMA. Bioinformatics 2004, 20(17):3252-3255[http:// dogma.ccbb.utexas.edu/].

36. Lowe TM, Eddy SR: A program for improved detection of transfer RNA genes in genomic sequence. tRNAscan-SE Search Server. Nucl Acids Res 1997, 25:955-964[http://selab.janelia.org/tRNAscan-SE/].

37. GenBank. [http://www.ncbi.nlm.nih.gov/].

38. Edgar RC: MUSCLE: multiple sequence alignment with high accuracy and high throughput. Nucl Acids Res 2004, 32(5):1792-1797.

39. Tamura K, Peterson D, Peterson N, Stecher G, Nei M, Kumar S: MEGA5: Molecular Evolutionary Genetics Analysis using Maximum Likelihood, Evolutionary Distance, and Maximum Parsimony Methods. Molecular Biology and Evolution 2011, 28(10):2731-2739.

doi:10.1186/1756-0500-4-400

Cite this article as: Danic-Tchaleu et al: Complete mitochondrial DNA sequence of the European flat oyster Ostrea edulis confirms Ostreidae classification. BMC Research Notes 2011 4:400.

\section{Submit your next manuscript to BioMed Central and take full advantage of:}

- Convenient online submission

- Thorough peer review

- No space constraints or color figure charges

- Immediate publication on acceptance

- Inclusion in PubMed, CAS, Scopus and Google Scholar

- Research which is freely available for redistribution

Submit your manuscript at www.biomedcentral.com/submit 